\title{
ІСТОРИКО-ПЕДАГОГІЧНІ ТА АКСІОЛОГІЧНІ АСПЕКТИ РОЗВИТКУ ПРОФЕСІЙНОЇ ОСВІТИ В УСРР В 20-Х РОКАХ ХХ СТОЛІТТЯ
}

Ternopil-Aberdeen, C. 178-185. DOI: https://doi.org/ 10.25128/2520-6230.20.2.3

6. Садова, I. (2017). Арт-терапія як ефективна технологія соціалізації дітей з особливими освітніми потребами в сучасних умовах. Педагогічні науки: теорія, історія, інноваційні технологї̈, № 1 (65), С. 272.

\section{REFERENCES}

1. Voznesenska, O. \& Mova, L. (2007). Art-terapiia v roboti praktychnoho psykholoha [Art therapy in the work of a practical psychologist]. The use of art technology in education. 125 p. [in Ukrainian].

2. Horishna, N. (2020). Rozvytok katehorii inkliuzyvna osvita u filosofsko-osvitnikh kontseptsiiakh ta suchasnomu naukovomu dyskursi [Development of the category of inclusive education in philosophical and educational concepts and modern scientific discourse]. Social Work and Education. Vol. 7, No. 1. Ternopil-Aberdeen, 2020. pp. 65-75. DOI: 10.25128/2520-6230.20.1.5. [in Ukrainian].

3. Zamashkina, O. D. (2020). Palchykova terapiia: mozhlyvosti zastosuvannia u reabilitatsii ditei $\mathrm{z}$ osoblyvymy potrebamy [Finger therapy: possibilities of application in rehabilitation of children with special needs]. BBK 83. p. 416. [in Ukrainian].

4. Kontseptsiia rozvytku inkliuzyvnoi osvity (2010). [The concept of inclusive education]. Available at: https:/ /mon.gov.ua/ua/npa/pro-zatverdzhennya-kontseptsiirozvitku-inklyuzivnogonavchannya [in Ukrainian].

5. Oliinyk, H. (2020). Osoblyvosti sotsializatsii ditei z osoblyvymy potrebamy u suchasnomu ukrainskomu suspilstvi [Features of socialization of children with special needs in modern Ukrainian society]. Social Work and Education. Vol. 7, No. 2. Ternopil-Aberdeen, pp.178-185. DOI: https://doi.org/10.25128/2520-6230.20.2.3 [in Ukrainian].

6. Sadova, I. (2017). Art-terapiia yak efektyvna tekhnolohiia sotsializatsii ditei z osoblyvymy osvitnimy potrebamy $\mathrm{v}$ suchasnykh umovakh [Art therapy as an effective technology for socialization of children with special educational needs in modern conditions]. Pedagogical sciences: theory, history, innovative technologies, No. 1 (65), p. 272. [in Ukrainian].

Стаття надійшла до редакції 11.02.2021

УДК: 378(091):377.091“19”

DOI:

Мирослав Пагута, кандидат педагогічних наук, доиент, дочент кафедри технологічної та професійної освіти, докторант кафедри загальної педагогіки та дошкільної освіти, Дрогобицький державний педагогічний університет імені Івана Франка

\section{ІСТОРИКО-ПЕДАГОГІЧНІ ТА АКСІОЛОГІЧНІ АСПЕКТИ РОЗВИТКУ ПРОФЕСІЙНОЇ ОСВІТИ В УСРР В 20-Х РОКАХ ХХ СТОЛІТТЯ}

Стаття присвячена розкриттю історико-педагогічних та аксіологічних аспектів становлення та розвитку професійної освіти в УСРР в 20-х рр. ХХ ст. Показано, щуо розвиток професійної освіти на території УСРР означеного періоду характеризується значними аксіологічними змінами.

Встановлено, щуо зміст державної політики означеного періоду в галузі професійної освіти був націлений на ідеї поєднання тогочасних більшовицько-сочіалістичних цінностей та ідеології з украӥнською гуманістичною та нацуіональною традицією.

Ключові слова: професійна освіта; цінності освіти; аксіологічні аспекти професійної освіти УСРР.

תim. 15.

Myroslav Pahuta, Ph.D.(Pedagogy), Associate Professor, Associate Professor of the Technological and Professional Science Department, Doctoral Student of the General Pedagogy and Preschool Education Department, Drohobych Ivan Franko State Pedagogical University

\section{HISTORICAL, PEDAGOGICALAND AXIOLOGICALASPECTS OF VOCATIONAL EDUCATION'S DEVELOPMENT IN THE USSR IN THE 1920s}

The article is devoted to the disclosure of the historical, pedagogical and axiological aspects of the vocational education's formation and development in the USSR in the 1920s. It is shown that the vocational education's development in the USSR in the 1920s is characterized by significant axiological changes.

An analysis of historical, pedagogical and axiological aspects of the vocational education's functioning and development in the USSR in the 1920s showed that one of the main goals of educational policy in general and in vocational education in particular was the creation and promotion of a single ideology and value system which manifested itself in the destruction of pre-revolutionary period's values, anti-religious propaganda and the establishment of a materialist Bolshevik-socialist worldview.

It is established that the positive aspects of the vocational education's development in the USSR of that 
period include the increase in the number of vocational education institutions, although this was accompanied by the low quality of education itself and its focus on ideology. Undoubtedly positive was the course of "Ukrainization" that was proclaimed during this period by the government of the USSR. It contributed to the development of the national system of vocational education in terms of inculcating national values along with class values and communist ideology. A characteristic feature of this period was the creation of its own original education system that was based on the professionalization and development of the national education system. In general, during this period the content of the state policy of the USSR in the field of vocational education was quite democratic in nature and was aimed at combining the Bolshevik-socialist and communist values, as well as its ideology, with humanistic and national traditions established in Ukrainian pedagogical thought and practice during the liberation period.

Keywords: vocational education; educational values; axiological aspects of vocational education in the USSR.

П остановка проблеми. Проблема реформування та розвитку професійної освіти в Україні на сьогодні є надзвичайно актуальною, іii розв'язок, безумовно, потребує грунтовного історико-педагогічного аналізу усіх аспектів становлення, розвитку та функціонування системи професійної освіти. Особливо гостро це стосується дослідження та переосмислення аксіологічних аспектів функціонування і розвитку професійної освіти на теренах України в різних історичних періодах, суспільно-політичних й ідеологічних умовах. Так, П. Лузан та О. Васюк зазначають, що ознайомлення зі шляхами розвитку теорії та практики навчання і виховання в різні історичні періоди і різних суспільноекономічних й ідеологічних умовах сприяє виробленню правильного ставлення до власної педагогічної спадщини, та допомагає критично осмислити і використати досвід минулого в сучасних реаліях, дозволяє побачити генезис багатьох педагогічних проблем та явищ $[7,6]$.

Аналіз досліджень. Проведений нами аналіз досліджень і публікацій з теми цієї статті, засвідчив, що запропонована проблема хоча і не нова, проте сьогодні відсутні цілісні студії аксіологічних аспектів функціонування та розвитку професійної освіти в УСРР у 20-х рр. XX ст. Водночас, різні аспекти аналізованої проблеми розкриваються у тогочасних постановах, декретах, указах РНК УСРР, ВУЦВК, резолюціях з’іздів КП(б)У та Рад робітничих, селянських і червоноармійських депутатів, збірниках законів та розпоряджень робітничо-селянського уряду України, енциклопедичних виданнях, працях і публікаціях тогочасних основних ідеологів створення самобутньої, національно орієнтованої системи освіти УСРР, українських педагогів та керівників освітньою галуззю - Г. Гринька, В. Дурдуківського, Я. Мамонтова, О. Музиченко, Я. Ряппо, М. Скрипника, Я. Чепіги тощо. Загальні аспекти функціонування та розвитку освіти й педагогіки в СРСР та УРСР присвятили свої праці О. Васюк, I. Лікарчук, Я. Ряппо, О. Сухомлинська тощо. Особливості професійної підготовки фахівців в
Україні розкриваються у працях таких науковців як О. Гаврилюк, Б. Гершунський, Г. Гринько, О. Кіяшко, П. Лузан, П. Олійник, С. Сисоєва та ін.

Мета статті полягає у розкритті історикопедагогічних й аксіологічних аспектів становлення і розвитку професійної освіти в УСРР 20-30-х рр. ХХ ст.

Виклад основного матеріалу. Розвиток професійної освіти на території УСРР у 20-х рр. XX ст. характеризується значними аксіологічними змінами. Так, одним із основних напрямів політики уряду УРСР у сфері освіти було створення єдиної системи цінностей більшовика. Прищеплювався ідеал борця-революціонера який живе ідеями світової революції та відкидає всі дореволюційні (традиційні) цінності. Тому політика уряду УРСР у сфері освіти, як і всього тогочасного Радянського союзу, насамперед полягала в знищенні традиційних дореволюційних цінностей, що проявлялося в антирелігійній пропаганді, знищенні класичних уявлень про сім'ю, шлюб, соціальний статус людини, побудову безкласового революційного суспільства. Як взірець висувався пролетарій-комуніст борець за побудову нового соціалістично-комуністичного світуз непримиренним ставленням до всього, що суперечить більшовицькій ідеології $[1,35]$. Велика увага приділяється політосвіті, спрямована на масову агітацію більшовицько-комуністичної ідеології та цінностей.

Так, А. Кравченко зазначає, що один із провідних тогочасних більшовитських ідеологів М. Бухарін заявляв, що перед ними стоїть надзвичайно важлива проблема - обробки людей та перетворення їх на такі живі машини, які б у всіх своїх діях керувалися новими цінностями та принципами нової пролетарської ідеології [6].

При цьому необхідно зазначити, що, на відміну від розвитку професійної освіти на території РСФРР, в УСРР 20-х рр. ХХ ст. розвивалася національна система освіти зі значно демократичнішими принципами й підходами та національно-орієнтованим характером.

Головним засобом ідеологічно-аксіологічного впливу більшовиків на молодь, у тому числі й на 


\section{ІСТОРИКО-ПЕДАГОГІЧНІ ТА АКСІОЛОГІЧНІ АСПЕКТИ РОЗВИТКУ ПРОФЕСІЙНОЇ ОСВІТИ В УСРР В 20-Х РОКАХ ХХ СТОЛІТТЯ}

теренах УСРР, була вибрана саме освіта та відповідно всі навчальні заклади. Саме освіта, як зазначалося у партійній програмі, мала стати не тільки провідником комуністичних принципів загалом, а і провідником ідейного, організаційновиховного впливу пролетаріату на напівпролетарські й не пролетарські верстви трудових мас з метою виховання більшовика-комуніста. Освіта була покликана забезпечити входження молодої людини в суспільне життя у тому числі й шляхом формування у неї комуністичного світогляду [6].

Так, 25 листопада 1922 р. було введено в дію Кодекс законів про народну освіту, якими, поміж інших, регламентувалися всі аспекти функціонування системи професійної освіти на усій території УСРР.

Для того, щоб диференціювати типи закладів професійної освіти від дореволюційних, законодавець відійшов від традиційного поділу школи на вищий, середній і нижчий ступені, а в основу типології поклав інтереси господарського та культурного життя, що детермінують ступінь необхідної кваліфікації у різних професіях.

Відтак за ступенем кваліфікації було встановлено такі ступені школи:

- для індустріально-технічної і сільськогосподарської галузей - профшкола, технікум та інститут;

- для соціально-економічної галузі - технікум та інститут;

- для педагогічної світи - інститут.

3 метою підвищення кваліфікації у соціальноекономічній та педагогічній освіті засновувалися різноманітні курси, а також організовувалися профшколи з художньої та медичної освіти.

Законодавством було визначено характерні ознаки різних типів закладів професійної освіти.

Початковою організаційною формою профосвіти для підлітків, масовим закладом загального обов'язкового навчання була визнана профшкола.

Технікум трактувався вищою школою для підготовки працівників вищої кваліфікації (інженерів-практиків, агрономів, господарників) конкретної вузької галузі народного господарства і державного будівництва.

Інститут реалізував підготовку організаторівкерівників вищої кваліфікації для широких галузей народного господарства та державного будівництва.

Формою перехідного часу визнавалися курси, які організовувалися переважно для дорослих, i характеризувалися гнучкістю навчальних планів та програм, актуальністю завдань, різною тривалістю і складом курсантів. Мета їхньої діяльності полягала як у підвищенні кваліфікації фахівців, так і в присвоєнні імм нової кваліфікації.

Законодавець передбачив також особливі пролетарські організаційні форми освіти, що виникали безпосередньо на виробництві. До них, зокрема, належали:

- школи робітничої молоді, метою яких було масове охоплення робітничої молоді безпосередньо на виробництві;

- вечірні робітничі технікуми, які організовувалися для робітників високої кваліфікації та мали на меті надання кваліфікації майстра, помічника інженера чи інженера вузької спеціальності;

- робітничі факультети, що засновувалися при інститутах та технікумах і мали на меті підготовку пролетаріату для вступу до вищої школи у відповідь на завдання їі завоювання i пролетаризації.

Законодавством було задекларовано проведення систематичної індустріалізації, агрономізації та політосвіти в усіх типах шкіл профосвіти. Індустріалізація й агрономізація досягалися заснуванням шкільних виробничих колективів на правах кооперації, залученням до роботи освітніх закладів відповідних підприємств, а також створенням шкільних господарств. Натомість політосвіта реалізувалася в обсязі політграмоти для профшкіл і курсів, а також в обсязі соціально-політичного наукового мінімуму для технікумів та інститутів [12].

Наприклад, аналіз змісту навчання у вищій школі засвідчив, що усюди обов'язковим було викладання суспільних та природничих наук. Суспільними науками, обов'язковими для вивчення, були: розвиток суспільних форм; історичний матеріалізм; пролетарська революція, історичні передумови перевороту, включаючи імперіалізм; його форми та історія в зв'язку з історією IX-XX ст. взагалі і робітничого руху зокрема; політичний лад РСФРР і УСРР; організація виробництва і розподілу в РСФРР і УСРР; план електрифікації РСФРР і УСРР, його економічні основи, економічна географія Росії і України, значення і умови здійснення плану. Природничі науки, що викладалися у всіх закладах вищої освіти, - фізика і космічна фізика, включаючи геофізику; хімія; біологія [10]. Включення до навчальних планів цих дисциплін мало на меті прищеплення студентам цінностей соціалізму, розвиток наукового атеїстичного світогляду.

Потрібно зазначити, що станом на кінець 1927 p. мережа вищих професійних закладів об'єднувала 37 інститутів та 144 технікумів, а кількість робітників і селян, які навчалися в інститутах, досягла $45 \%$, у технікумах - $68 \%$, решта 


\section{ІСТОРИКО-ПЕДАГОГІЧНІ ТА АКСІОЛОГІЧНІ АСПЕКТИ РОЗВИТКУ ПРОФЕСІЙНОЇ ОСВІТИ В УСРР В 20-Х РОКАХ ХХ СТОЛІТТЯ}

студентів - діти радянської інтелігенції. Було зрозумілим, що професійних шкіл, особливо для селянської молоді, недостатньо порівняно 3 темпами зростання промисловості, сільського господарства і всього господарського життя. Тому було взято курс на збільшення кількості професійних навчальних закладів. Так, вже станом на 1929 р. налічувалося 239 високих шкіл, в яких навчалися 88621 особа [5, 936].

Однак реформи професійної, зокрема, вищої, освіти практично не посприяли підвищенню i достатньо низької якості. Політизація та ідеологізація освіти, викорінення 3 неї “неблагонадійних елементів" з-поміж як викладачів, так і студентства, прискорення підготовки та спрощення вимог до знань вступників відбилися на ній настільки негативно, що вже в середині 20-х pp. ХХ ст. це змушений був визнати і Я. Ряппо - головний реформатор і заступник народного комісара освіти УСРР.

Зокрема, загальний рівень тогочасного українського студентства був дуже низьким. Сприяв цьому і виданий на початку 1919 р. Декрет РНК УСРР "Про вступ до вищої школи” [4], відповідно до якого усі (класово-благонадійні особи), хто бажав отримати вищу освіту, могли це зробити. Від вступників заборонялося вимагати дипломи чи будь-які інші документи про освіту, крім посвідчення особи і віку, що, своєю чергою, призвело до того, що тогочасне студентство у визначальній своїй більшості було малограмотне або й взагалі безграмотне. Оскільки доступ до вищої освіти “класово-чужим" та "неблагонадійним елементам" таких як діти заможних селян - “куркулів”, поміщиків, духівництва, купців та фабрикантів тощо) був заборонений то тогочасне українське студентство, походило передовсім практично неграмотного пролетаріату та бідного селянства.

Показовим прикладом важливості для радянської влади “правильного соціальнокласового походження” може служити те, що сам Я. Ряппо - заступник народного комісара освіти УСРР, позиціював себе як трудовий інтелігент із селян [15] (тобто - класово благонадійний), про що наголошує у власноручно заповненій анкеті.

Також вільний доступ до вищої професійної освіти отримують представники партійнорадянської номенклатури та їх родичі, діти так званої “трудової інтелігенції” або “радянської інтелігенції” (вчителів, службовців, технічних та інших спеціалістів тощо).

Водночас, окрім зростання кількості професійних навчальних закладів, зверталася увага на недостатню якість навчання. Так, резолюцією Х з'їзду КП(б)У “Про завдання культурного будівництва на Україні” звертається увага на недостатню якість навчання у багатьох професійних та трудових школах, адже значна кількість випускників не мають необхідного для життя досвіду і знання, не готові до складання вступних іспитів до вищих шкіл. Щодо вищих шкіл наголошувалося не необхідності підсилення практичної підготовки студентів, збільшення частки селян та робітників серед студентської молоді тощо [13, 396-397].

Варто відзначити, що й шкільна освіта базувалася на ідеях про трудову діяльність людей та їхню виробничу працю, що логічно випливають 3 точки зору історичного матеріалізму 3 природничо-наукового уявлення про працю як основу життя. Більше того, поєднуючись із виробництвом, усі заклади освіти (включно зі школою) складали єдину систему професійної освіти УСРР.

Зокрема, з цього приводу, обгрунтовуючи відмінності російської і української систем освіти, Г. Гринько писав: умовну схему першої можна зобразити у вигляді основної дороги загальноосвітніх закладів і бічної-профтехнічної освіти. Натомість українська схема знищує це протиставлення. Правий бік витісняє лівий і розвертається відповідно до основних галузей господарського і державного життя. Таким чином замість двох нерівних за обсягом, питомою вагою і значущістю частин освітньої системи українська схема розгортає єдину систему профтехнічної спеціально-наукової освіти. Автор також резюмує: широка професійна освіта $€$ не зовнішнім додатком до загальної освіти, а ії основним і могутнім джерелом [2, 88-90].

Крім масовості професійної освіти, у 20-ті рр. XX ст. варто відзначити ще й інші тенденції українізацію освіти, на чому особливо наполягав комісар освіти М. Скрипник, а також їі ідеологізацію.

Здійснюючи ідеологізацію змісту діяльності шкіл, радянська адміністрація була змушена поступитися українським рухам, проголосивши курс офіційної українізації $[5,935]$. Так, Декретом РНК УСРР від 27 липня 1923 р. "Про заходи в справі українізації шкільно-виховних і культурновиховних установ" передбачалося введення викладання українською мовою:

- на вищих 3-річних педагогічних курсах, факультетах соціального виховання - інститутів народної освіти, у Київському IHО, у школах сільськогосподарської та соціально-економічної освіти;

- у Київському медичному інституті та 


\section{ІСТОРИКО-ПЕДАГОГІЧНІ ТА АКСІОЛОГІЧНІ АСПЕКТИ РОЗВИТКУ ПРОФЕСІЙНОЇ ОСВІТИ В УСРР В 20-Х РОКАХ ХХ СТОЛІТТЯ}

медичних школах, що обслуговували українське населення;

- у всіх художніх школах на Правобережжі, Полтавщині та, по можливості, в інших губерніях.

Передбачалося також введення у школах профосу з викладанням російською мовою окремих циклів дисциплін українською мовою. А вже 31924 р. вводилося обов'язкове вивчення у всіх професійних школах української мови, а також спеціальних курсів українознавства [3]

Однак насаджувана згори негайна українізація усіх фахових і технічних середніх, а також вищих шкіл часто мала формальний характер, що пов'язувалося 3 браком часу на підготовку викладачів і друк нових підручників [5, 935]. Наприклад, у 1925/26 н. р. навчання українською мовою велося у 43,8 \% міських і 81,9 \% сільських шкіл. У професійних школах ситуація була ще гіршою. Було українізовано 51,9 \% профшкіл, 54 \% технікумів, 28,5 \% інститутів [13, 401]. Станом на 1929 р. українізовано 81 \% трудових шкіл, 51,4 \% профшкіл, 54 \% технікумів та $30 \%$ інститутів [11].

Ревізія досягнень та успіхів народної освіти в Україні у перші роки радянської влади засвідчила стабільність та ефективність мережі вищих шкіл. Натомість вказувалося, що послідовно зростати має мережа професійних та сільськогосподарських шкіл. Індустріалізація актуалізувала акцент на робітничій освіті. Робітничі професійні курси, вечірні професійні школи та технікуми, школи фабзавучу, курси майстрів тощо мали зміцнюватися. Наголошувалося на необхідності поліпшення навчальних програм та посиленні їхнього забезпечення підручниками та іншими дидактичними засобами [9].

Зверталася увага на наступність усіх ланок системи освіти таким чином, щоб для кожного учня, робітника, селянина забезпечувалася можливість безпосереднього переходу від найнижчих ступенів трудових шкіл через професійну школу до вищого навчального закладу та науково-дослідницької діяльності.

Перегляд завдань, що стояли перед різними типами закладів освіти, дає змогу констатувати, що завданням усієї освітньої системи стало виховання трудівника, який володіє широкими знаннями і методами розуміння природи та суспільства й підготовленого до творчої діяльності у суспільному виробничому процесі.

Надалі стверджувалося на необхідності усунення з усієї системи народної освіти будь-яких конфесійно-релігійних впливів, а натомість актуалізувалася потреба побудови системи освіти і всіх методів викладання й навчання на засадах наукового світогляду та матеріалістичного методу задля підготовки 3 дітей та молоді свідомих, активних громадян пролетарської республіки.

Система освіти розглядалася як єдиний державний апарат для проведення комуністичної пропаганди. Вона декларувалася національною за мовою, формою і матеріалом, а також пролетарською, колективістською та інтернаціональною за змістом [13, 391-393].

Висновки. Аналіз історико-педагогічних та аксіологічних аспектів функціонування і розвитку професійної освіти в УСРР 20-х рр. ХХ ст. засвідчив, що однією з основних цілей освітньої політики загалом та в галузі професійної освіти зокрема було створення і пропагування єдиної ідеології та системи цінностей радянського суспільства, що проявлялося у знищенні цінностей дореволюційного періоду, антирелігійній пропаганді й утвердженні матеріалістичного більшовитсько-соціалістичного світогляду.

Встановлено, що до позитивних аспектів розвитку професійної освіти УСРР того періоду можна віднести зростання кількості навчальних закладів професійної освіти, хоча це й супроводжувалося низькою якістю самої освіти та її заідеологізованістю.

Так, автори праці “Модернизация в России и конфликт ценностей” зазначають, що проведений ними аналіз ціннісних аспектів розвитку професійної освіти впродовж перших років радянської влади засвідчив, що прискорені темпи масової освіти і професійної підготовки сприяли швидкому поширенню цінностей, грунтом для яких завжди було невігластво: прихильність до формального знаку рівня освіти (атестат, диплом, знання) і нехтування фактичним володінням знаннями і навичками; схвалення загальнодоступності іпростотиусфері пізнання; передача готового знання, а не пошук нового; утвердження пріоритету самодіяльного мистецтва, раціоналізаторства і винахідництва над професійним розв'язанням соціокультурних проблем [8, 88].

Загалом зміст державної політики УСРР в означений період у галузі професійної освіти мав достатньо демократичний характер та був спрямований на ідеї поєднання тогочасних більшовитсько-соціалістичних і комуністичних цінностей та ідеології 3 національною і гуманістичною традицією, що утвердилася в українській педагогічній думці та практиці у період визвольних змагань.

У цьому контексті, безумовно, позитивним став проголошений урядом УСРР курс на “українізацію”, що сприяло розвитку національної системи професійної освіти, в аспекті прищеплення національних цінностей разом 3 


\section{ІСТОРИКО-ПЕДАГОГІЧНІ ТА АКСІОЛОГІЧНІ АСПЕКТИ РОЗВИТКУ ПРОФЕСІЙНОЇ ОСВІТИ В УСРР В 20-Х РОКАХ ХХ СТОЛІТТЯ}

класовими цінностями та комуністичною ідеологією. Характерною особливістю цього періоду стало створення власної, оригінальної системи освіти, в основі якої лежали професіоналізація та розбудова національної системи освіти $[14,58-59]$.

\section{ЛІТЕРАТУРА}

1. Анашкина Г.П. История и культура России XX века в нравах: Хрестоматия. Ульяновск: УлГТУ, 2006. $172 \mathrm{c.}$

2. Гринько Г. Система Наркомпроса Украины. Советская производственно-трудовая школа. Педагогическая хрестоматия. / под. ред. А. Калашникова. Москва : Издательство “Работник просвещения", 1925. С. 88-94.

3. Декрет РНК УСРР від 27 липня 1923 р. “Про заходи в справі українізації шкільно-виховних і культурно-освітніх установ". Збірник законів та розпоряджень робітничо-селянського уряду України. 1923. № 29. Ст. 430.

4. Декрет РНК УСРР "Про вступ до вищої школи”. Збірник законів та розпоряджень робітничо-селянського уряду Украӥни. 1919. № 20. Ст. 212.

5. Енциклопедія українознавства. Загальна частина. Київ, 1995. 1230 с.

6. Кравченко А. Создание нового советского человека. Лекция 3 из 8. Как большевики превращали человека в машину, чего они хотели от детей и зачем были нужны пионеры. URL : https://arzamas.academy/materials/1499

7. Лузан П.Г., Васюк О.В. Історія педагогіки та освіти в Україні: навчальний посібник /2-ге вид., доп. і перероб. Київ: ДАКККіМ, 2010. 296 с.

8. Модернизация в России и конфликт цінностей / А.П. Ахнезар, Н.Н. Козлова, С.Я. Матвеева. Москва : Изд-во ИФ РАН, 1994. 250 с.

9. Постанова Політбюро ЦК КП(б)У “Про стан народної освіти на Україні”. Комуніст. 1927. 2 березня. № 50.

10. Постанова РНК УСРР від 26 квітня 1921 р. "Про встановлення загального наукового мінімуму, обов'язкового для викладання в усіх вищих учбових закладах". Збірник законів та розпоряджень робітничо-селянського уряду Украӥни. 1921. № 7. Ст. 216.

11. Постанова ХІ Всеукраїнського з’їзду Рад робітничих, селянських і червоноармійських депутатів від 15 травня 1929 р. "Про стан і перспективи культурного будівництва”. Збірник закопів і розпоряджень Робітничо-Селянського уряду Украӥни. 1929. № 19. СТ. 156.

12. Постановление ВУЦВК от 22 ноября 1922 г. “О введении в действие Кодекса законов о народном образовании”. Собрание узаконений и распоряжений Рабочего и Крестьянского правительства. 1922. № 49. Ст. 729.

13. Резолюція Х з'їзду КП(б)У “Про завдання культурного будівництва на Україні”. Комуністична партія України в резолюціях $\mathrm{i}$ рішеннях з'їздів і конференцій. Київ : Держполітвидав УРСР, 1958. С. 391-412.

14. Сухомлинська О.В. Історико-педагогічний процес: нові підходи до загальних проблем. Київ: А.П.Н., 2003. 68 с.

15. Центральний державний архів вищих органів влади та управління (ЦДАВО України). ф. 1. Оп. 11. Спр. 3184 . Арк. 3.

\section{REFERENCES}

1. Anashkina, G.P. (2006). Istoriya i kultura Rossii XX veka v nravakh: Khrestomatiya [History and culture of Russia of the XX century in customs: a reader]. Ulyanovsk, 172 p. [in Russian].

2. Grinko, G. (1925). Sistema Narkomprosa Ukrainy. Sovetskaya proizvodstvenno-trudovaya shkola. Pedagogicheskaya khrestomatiya [The system of the People's Commissariat for Education of Ukraine. Soviet industrial and labor school]. Pedagogical reader. (Ed.). A. Kalashnikova. Moscow. pp. 88-94. [in Russian].

3. Dekret RNK USRR vid 27 lypnia 1923 r. "Pro zakhody v spravi ukrainizatsii shkilno-vykhovnykh i kulturno-osvitnikh ustanov" (1923). [Decree of the SNC of the USSR of July 27, 1923 "On measures to Ukrainianize school and cultural and educational institutions"]. Collection of laws and orders of the workers and peasants' government of Ukraine. No.29. Art. 430. [in Ukrainian].

4. Dekret RNK USRR "Pro vstup do vyshchoi shkoly" (1919). [Decree of the SNC of the USSR "On admission to higher education"]. Collection of laws and orders of the workers "and peasants" government of Ukraine. No.20. Art. 212. [in Ukrainian].

5. Entsyklopediia ukrainoznavstva. Zahalna chastyna (1995). [Encyclopedia of Ukrainian Studies. The general part]. Kyiv, 1230 p. [in Ukrainian].

6. Kravchenko, A. Sozdanie novogo sovetskogo cheloveka. Lekcziya 3 iz 8 . Kak bolsheviki prevrashhali cheloveka v mashinu, chego oni khoteli ot detej i zachem byli nuzhny pionery [Creation of a new Soviet man. Lecture 3 of 8 . How the Bolsheviks turned a man into a machine, what did they want from children and why pioneers were needed]. Available at : https://arzamas.academy/materials/ 1499. [in Russian].

7. Luzan, P.H. \& Vasiuk, O.V. (2010). Istoriia pedahohiky ta osvity v Ukraini: navchalnyi posibnyk 
[History of pedagogy and education in Ukraine: textbook]. 2nd ed., Ext. and processing. Kyiv, 296 p. [in Ukrainian].

8. Modernizacziya v Rossii i konflikt czennostej (1994). [Modernization in Russia and the Conflict of Values]. (Eds.). Akhnezar A.P., Kozlova N.N., Matveeva S.Ya. Moscow, 250 p. [in Russian].

9. Postanova Politbiuro TsK KP(b)U "Pro stan narodnoi osvity na Ukraini" (1927). [Resolution of the Politburo of the Central Committee of the CP (b) $\mathrm{U}$ "On the state of public education in Ukraine"]. Communist. 2 March. No.50. [in Ukrainian].

10. Postanova RNK USRR vid 26 kvitnia $1921 \mathrm{r}$. "Pro vstanovlennia zahalnoho naukovoho minimumu, oboviazkovoho dlia vykladannia v usikh vyshchykh uchbovykh zakladakh" (1921). [Resolution of the SNC of the USSR of April 26, 1921 "On the establishment of a general scientific minimum, mandatory for teaching in all higher education institutions"]. Collection of laws and orders of the workers "and peasants" government of Ukraine. No.7. Art. 216. [in Ukrainian].

11. Postanova XI Vseukrainskoho zizdu Rad robitnychykh, selianskykh i chervonoarmiiskykh deputativ vid 15 travnia 1929 r. "Pro stan i perspektyvy kulturnoho budivnytstva” (1929). [Resolution of the XI All-Ukrainian Congress of Soviets of Workers', Peasants' and Red Army Deputies of May 15, 1929 "On the state and prospects of cultural construction"]. Collection of burials and orders of the Workers "and Peasants" Government of Ukraine. No.19. Art. 156. [in Ukrainian].

12. Postanovlenie VUCzVK ot 22 noyabrya $1922 \mathrm{~g}$. "O vvedenii v dejstvie Kodeksa zakonov o narodnom obrazovanii" (1922). [Decree of the All-Union Central University of Central Asian Affairs dated November 22, 1922 "On the introduction of the Code of Laws on Public Education"]. Collection of legalizations and orders of the Workers "and Peasants" government. No.49. Art. 729. [in Russian].

13. Rezoliutsiia X zizdu KP(b)U "Pro zavdannia kulturnoho budivnytstva na Ukraini” (1958). [Resolution of the X Congress of the CP (b) U "On the tasks of cultural construction in Ukraine"]. The Communist Party of Ukraine in resolutions and decisions of congresses and conferences. Kyiv, pp. 391-412. [in Ukrainian].

14. Sukhomlynska, O.V. (2003). Istorykopedahohichnyi protses: novi pidkhody do zahalnykh problem [Historical and pedagogical process: new approaches to general problems]. Kyiv, 68 p. [in Ukrainian].

15. Tsentralnyi derzhavnyi arkhiv vyshchykh orhaniv vlady ta upravlinnia (TsDAVO Ukrainy). f. 1. Op. 11. Spr. 3184. Ark. 3. [Central State Archive of Higher Authorities and Administration (TSDAVO of Ukraine). Fund 1. Description 11. Case 3184. Arc. 3.]. [in Ukrainian].

Стаття надійшла до редакції 10.02.2021

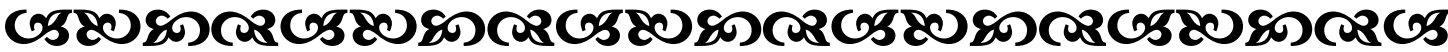

"Немає години, непридатної для занять корисними науқами, $і$ хто помірно, але постійно вивчає предмети, корисні як в цьому, так $і$ в майбутньому житті, тому навчання - не труд, а втіха... Хто думав про науку, той любить ї̈, а хто й любить, той ніқоли не перестає учитись, хоча б зовні він і здавався бездіяльним".

Тригорій Сковорода

украӥнський просвітитель-гуманіст, боілособ, поет, педагог

“Знання қращі за багатства, адже одне сқороминуще, а інше - вічне”.

Cоқрат

давнъогрецький ббілособб

“Фля вченої й освіченої людини жити - значить мислити”.

Квінт भुиерон

давньоримський оратор, похітик

“Не важливо з яқою швидкістю ти рухаєшся до своєї мети, головне не зупинятися".

Конбуучій

давнъокитайський ббілособб

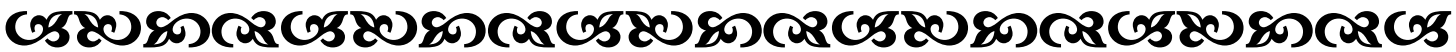

